\title{
The Effect of Allicin on Innate Immune Genes of \\ Common Carp (Cyprinus carpio L)
}

\author{
Jean Fall (Corresponding author) \\ Graduate Institute of Fisheries and Aquaculture (GIFA), \\ University Cheikh Anta DIOP of Dakar (UCAD), Senegal
}

Tel: 221-779-564-339_E-mail: kagoshima77@yahoo.com

Mahmoud Tanekhy

Fish Diseases Dept., Faculty of Veterinary Medicine, Alexandria University, Egypt

Received: September 10, 2015 Accepted: October 20, 2015 Published: October 26, 2015

Doi: 10.5296/jab.v4i1.8281 URL: http://dx.doi.org/10.5296/jab.v4i1.8281

\begin{abstract}
Garlic is known to possess a vast variety of biological functions. It was reported to be an antimicrobial, antithrombotic, anticacer, antioxidant and could improve the immune-system as well as had the capacity to lower serum lipid and glucose levels. The impact of allicin on signaling pathways still needs to be investigated and reports about its effect on cytokine production are inconsistent. In the present study, we investigated the influence of allicin on several carp genes and checked the immediate response of these genes. Direct p-regulation of pro-inflammatory cytokines as IL- $1 \beta$, TNF- $\alpha$, IL-10, TLR3, and INF- $\alpha$, INF $\gamma 1$ was observed after stimulation of carp head kidney (HK) cells with allicin extract. These results strongly indicate that allicin is responsible for the anti-inflammatory effects. Further, the results suggest that there are potential therapeutic effects of allicin on chronic inflammatory diseases. These effects need more investigations in aquaculture industries.
\end{abstract}

Keywords: Garlic, Fish, Immune genes, Diseases.

\section{Introduction}

Disease control is a major issue to the aquaculture industry; therefore it is of a great importance to prevent the outbreak of disease during the culture of commercially important fish species. One alternative way of prevention is the use of immunostimulants that affect the host rather than the pathogen, elevating nonspecific and specific host defenses.

Garlic's historic and worldwide medicinal uses have made it one of the most extensively studied medicinal herbs. However, the actual curative benefits of this member of the 


\section{Mll Macrothink}

Liliaceae family are unclear. Garlic is considered safe by the food drug administration (FDA), based on the lack of known serious adverse outcomes despite culinary and medicinal use throughout human history. The main purported active ingredient, allicin, is degraded by crushing, heat, and acid; thus, efficacy is optimized by consuming raw cloves or enteric-coated tablets. The usual dose is $300 \mathrm{mg}$, taken 2 to 3 times per day, standardized to at least $1.3 \%$ allicin (equivalent to approximately $3 \mathrm{~g}$ or 1 fresh clove daily. The enzyme allinase converts alliin to allicin (diallyl thiosulphinate), which is an extremely unstable compound that is responsible for the pungent smell of garlic (Block, 1985). It becomes quickly decomposed into organo-sulphur compounds, i.e. diallyl sulphide (DAS), diallyl disulphides (DADS), polysulphides and ajoenes (Miron et al., 2004). S-allyl cysteine is a relatively stable, odorless, bioavailable and water-soluble compound and is considered to contribute to the pharmacological and immunological activities of garlic (Corzo-Martinez et al., 2007). Allicin diallyl thiosulphinate is an active but volatile compound of garlic. It has been implicated in antibacterial activity against a wide range of Gram-positive and Gram-negative bacteria, and has antiviral, antifungal and anti-protozoal activity (Rose et al., 2005). It has been found that the antioxidant allicin scavenges $\mathrm{OH}$ and inhibits lipid peroxidation. Higher doses $(>100 \mu \mathrm{M})$ of allicin have proven toxic to mammalian cells (Hasan et al., 2007). Moreover, Shahsavani et al. (2011) showed that allicin supplementation is effective in decreasing lead accumulation in all examined tissues of common carp. The promising ameliorative effects of allicin on tissue lead levels of common carp make it a good candidate for therapeutic intervention of lead poisoning. Miron et al. (2000) concluded that allicin could easily diffuse into the internal volume of vesicles or into the cytoplasm of red blood cells. Allicin have the ability in preventing immune mediated concanavalin A-induced liver damage in mice (Santhosha et al., 2013). Allicin modulates the effect of T-cells and adhesion molecules and exerts an inhibitory effect on NF-kappa B activation and hence prevents liver damage. Studies have also suggested that allicin could be used therapeutically in treating chronic inflammatory diseases like inflammatory bowel disease.

Cytokines are small glycoproteins involved in extracellular signaling and play a significant role in balancing host immune responses. Based on their structural features, cytokines have been grouped into several families, including Interleukins (IL) such as IL-1, -2, -6, -12, -10, -17, Tumor necrosis factors (TNFs), transforming growth factors, and chemokines (Vilcek, 2003). These molecules regulate local and systemic immune inflammatory and regulatory events. The differentiation of Th cells into Th1-Th2 cells is important as hosts mount effective immune responses. The differentiation and balance between Th1-Th2 type response is predominately mediated by the respective cytokines. Previously, identification of fish cytokines was based mainly on EST- and PCR-mediated homology cloning using degenerate PCR primers (Savan \& Sakai, 2006).

Several fish cytokine genes have been isolated and characterized in recent years, and researchers have used mRNA expression as a tool for measuring immune responses (genomic database of zebrafish and fugu). Although not all genes discovered by homology cloning may encode for proteins with the same function as the query genes, it appears that fish have most of the cytokines relevant to responses to bacteria, viruses, inflammation, or cell proliferation and chemo-attraction. In particular, pro-inflammatory cytokines, including IL- $1 \beta$, TNF- $\alpha$, 
IL-8, IL-12, INFs, and IL-10 are commonly used immune-regulatory genes in fish (Castillo et al., 2009; Tanekhy et al., 2010).

The present study was carried out to investigate the effect of allicin, a crude garlic extract on the immune related genes expressions in the common carp, Cyprinus carpio L.

\section{Material and Methods}

\subsection{Fish}

Adult common carp (mean mass 300g) were obtained from Susano farm, Miyazaki, Japan. They were checked thoroughly for injury and disease conditions, and only healthy fishes were used for this study. After washing with $0.01 \% \mathrm{KMnO} 4$ solution for $15 \mathrm{~min}$, they were placed in nine plastic pools $(500 \mathrm{~L})$ containing non-chlorinated water. Prior to the start of the experiment, the fishes were acclimatized to the food and laboratory conditions with $12 \mathrm{~h}$ dark and $12 \mathrm{~h}$ light cycles, $\mathrm{pH}$ range of 6.95 to 7.60 and temperature ranging from 16 to $24{ }^{\circ} \mathrm{C}$ for 15 days.

\subsection{Allicin (Garlic extract)}

Fresh garlic cloves $(70 \mathrm{~g})$ were blended in $35 \mathrm{ml}$ distilled $\mathrm{H} 2 \mathrm{O}$, centrifuged, ultra-filtered through a $10 \mathrm{kDa}$ cut-off membrane (Flowgen, UK) and sterilized by filtration $(0.45 \mathrm{~mm})$. By subtracting the weight of the insoluble material from the weight of the original cloves, the final concentration of the garlic extract in solution was determined to be $57.1 \%(\mathrm{w} / \mathrm{v})$. Aliquots were stored at $-20{ }^{\circ} \mathrm{C}$ until required.

\subsection{In vitro Stimulation Using Allicin}

A preliminary in vitro stimulation test using different concentrations of allicin was conducted. The in vitro stimulation test was done by using concentration of $6 \mu \mathrm{g} / \mu \mathrm{l}, 12 \mu \mathrm{g} / \mu \mathrm{l}, 25 \mu \mathrm{g} / \mu \mathrm{l}$ and $50 \mu \mathrm{g} / \mu \mathrm{l}$ of allicin at $4 \mathrm{~h}$ post-stimulation. The lower concentration of allicin $6 \mu \mathrm{g} / \mu \mathrm{l}$ resulted in a significant increase of all immune genes used in this study. However, higher concentrations of 25 and $50 \mu \mathrm{g} / \mu \mathrm{l}$ resulted in a marked decrease in these genes (unpublished data). Therefore, we decided to use the concentration of $6 \mu \mathrm{g} / \mu \mathrm{l}$ of allicin for the gene expression study.

The head kidney (HK) cells of five fish were isolated according to the modified method described by Braun-Nesje et al (1982). The cells were removed from the fish and filtered through a nylon mesh with RPMI 1640 medium (Nissui, Japan) containing $1 \%$ streptomycin / penicillin (S/P, Gibco, USA), 0. 2\% heparin (Sigma, USA) and $10 \%$ carp serum (CS). HK cells of carp were evenly dispersed in the RPMI 1640 medium and stimulated with $6 \mu \mathrm{g} / \mu \mathrm{l}$ of allicin at $0 \mathrm{~h}$ (control), $1 \mathrm{~h}, 4 \mathrm{~h}, 8 \mathrm{~h}$, and $12 \mathrm{~h}$ post-stimulation at $22{ }^{\circ} \mathrm{C}$, in RPMI 1640 medium supplemented with $50 \mu \mathrm{g} / \mathrm{ml}$ of ampicillin.

\subsection{Expression Analysis of Carp Cytokine Genes}

\subsubsection{RT-PCR}

Total RNA was isolated from treated Carp HK cells using ISOGEN (Nippon Gene, Osaka, Japan) according to the manufacturer's instructions. cDNA synthesis was then performed using ReverTra Dash (Toyobo, Osaka, Japan). Using the synthesized cDNA as a template, PCR reactions were performed according to the following protocol: $1 \mu \mathrm{L}$ of cDNA was mixed with $5 \mu \mathrm{L}$ of dNTPs $(10 \mu \mathrm{M}$ of each dNTP) and 10× Gene Taq Universal buffer, 0.5 
$\mu \mathrm{L}$ of Taq polymerase ( 5 units/ $\mu \mathrm{L}), 5 \mu \mathrm{L}$ of each specific primer $(5 \mu \mathrm{M})$ and $28.5 \mu \mathrm{L}$ of distilled water. Specific carp $\beta$-actin primers served as internal control. Expression levels of the carp interleukin (IL)-1 $\beta$ (AB010701; Fujiki et al., 2000), IL-10 (AB1110780; Savan et al., 2003), type1 INF (Kitao et al, 2009), INF $\gamma 1$, INF $\gamma 2$, TLR3 and TNF - $\alpha$ (AB112424; Saeij et al., 2003) have been performed. The sequences, annealing temperature and PCR product size for each of the specific primer pairs for carp $\beta$-actin and the cytokines observed in this study are outlined in Table 1.

Table 1. Common carp immune related genes primers and the PCR conditions with accession numbers

\begin{tabular}{|c|c|c|c|c|c|}
\hline Primers & Sequence $\left(5^{\prime}-3^{\prime}\right)$ & Cycle No & An. Temp $\left({ }^{\circ} \mathrm{C}\right)$ & Amplicon size (bp) & Accession No. \\
\hline INF- $\alpha \mathrm{F}$ & TGCATATGGCTCGGCCAATA & 35 & 61 & 804 & AB376667 \\
\hline INF- $\alpha$ R & GTCAAGACAAGAAACCTCACC & & & & \\
\hline IL-1 $1 \beta \mathrm{F}$ & GGAGAATGTGATCGAAGAGC & 30 & 61 & 280 & AJ245636 \\
\hline IL-1 $1 \beta R$ & GTAGAGGTTGCTGTTGGA & & & & \\
\hline IL-10 F & TGATGACATGGAACCATTACTGG & 30 & 60 & 284 & AB110780 \\
\hline IL-10 R & САСCTTTTTCCTTСАТСТTTTCA & & & & \\
\hline TNF- $\alpha \mathrm{F}$ & GCTGTCTGCTTCACGCTC & 30 & 58 & 188 & AJ311800 \\
\hline TNF- $\alpha \mathrm{R}$ & AAAGCCTGGTCCTGGTTC & & & & \\
\hline INFY1 F & GTCGCTGCTGCTTGATAGAA & 32 & 60 & 166 & AM261214 \\
\hline INFY1 R & CTGAAGCTCCCTCCATACTT & & & & \\
\hline INFy2 F & GAGGAACCTGAGCAGAATCT & 32 & 60 & 202 & AM168523 \\
\hline INFY2 R & CCTTGATCGCCCATAGTGTT & & & & \\
\hline TLR3 F & GCAGCACAACAACTTGGCTA & 32 & 59 & 197 & DQ885910 \\
\hline TLR3 R & CATGCAGCTGATCCAAGAGA & & & & \\
\hline$\beta$-actin F & ACCTCATGAAGATCCTGACC & 24 & 60 & 312 & M24113 \\
\hline$\beta$-actin R & TGCTAATCCACATCTGCTGG & & & & \\
\hline
\end{tabular}

PCR products were electrophoresed on a $1.5 \%$ agarose gel to detect the specific gene bands.

\subsection{Semi-Quantitative Analysis of RT-PCR Products}

Semi-quantitative analysis was undertaken in accordance to the method described by Kono et al. (2004). The carp cytokine / $\beta$-actin gene ratio and shrimp genes / EF ratio were determined by densitometry, undertaken by measuring photo-stimulated luminescence values using SCIENCE LAB99 IMAGE GAUGE software (Fujifilm, Tokyo, Japan), and by comparing the transcript levels of these genes to the internal genes.

\subsection{Statistical Analysis}

Data is expressed as mean \pm SEM. PCR results for the infected and control groups were analyzed using ANOVA and Tukey's significant difference tests. 


\section{Mll Macrothink}

\section{Results and Discussion}

Some adjuvants and immunostimulant substances such azadirachtin, chitin, CpG-ODNs, sodium alginate and iota-carrageenan, yeast, $\beta$-glucans as well as bacterial polysaccharides are commonly used to prevent occurrence of disease and to enhance immunity of fish. $\beta$-glucan administration has been reported to increase antibody production, complement activity, lysozyme activity, macrophage activity and respiratory burst of channel catfish Ictalurus punctatus, rainbow trout Oncorhynchus mykiss, Atlantic salmon Salmo salar, and gilthead seabream Sparus auratus. It is demonstrated that dietary garlic or garlic extract allicin enhance the non-specific immune mechanism of rainbow trout Oncorhynchus mykiss by stimulating the proliferation of immune cells, and enhancing phagocytosis, oxidative burst and lysozyme activities, Nya and Austin (2009, 2010) and Agatha A. Nwabueze (2012).

The pro-inflammatory cytokine (TNF- $\alpha)$ is key components in innate immunity and the inflammatory response in fish (Saeij et al., 2003). TNF- $\alpha$ is also an important macrophage-activating factor (MAF) produced by leukocytes. It is synthesized by various cell types upon stimulation with endotoxin, inflammatory mediators, or cytokines such as IL-1 $\beta$, and in an autocrine manner, upon stimulation by TNF- $\alpha$ itself (Hirono et al., 2000). Expression studies, particularly those conducted in vitro, have generally demonstrated that TNF- $\alpha$ mRNA expression and regulation in trout, carp, and flounder is similar to that observed in mammals, with similar activation kinetics (Wang \& Secombes, 2013). In the present study, the expression of TNF- $\alpha$ was significantly increased 1 and 4 hours post stimulation as compared to the control group, the highest expression of the IL-10 gene was observed 4 hours post stimulation (Figure 1). 


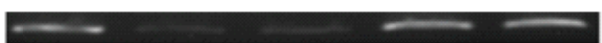

IL-1 $\beta$
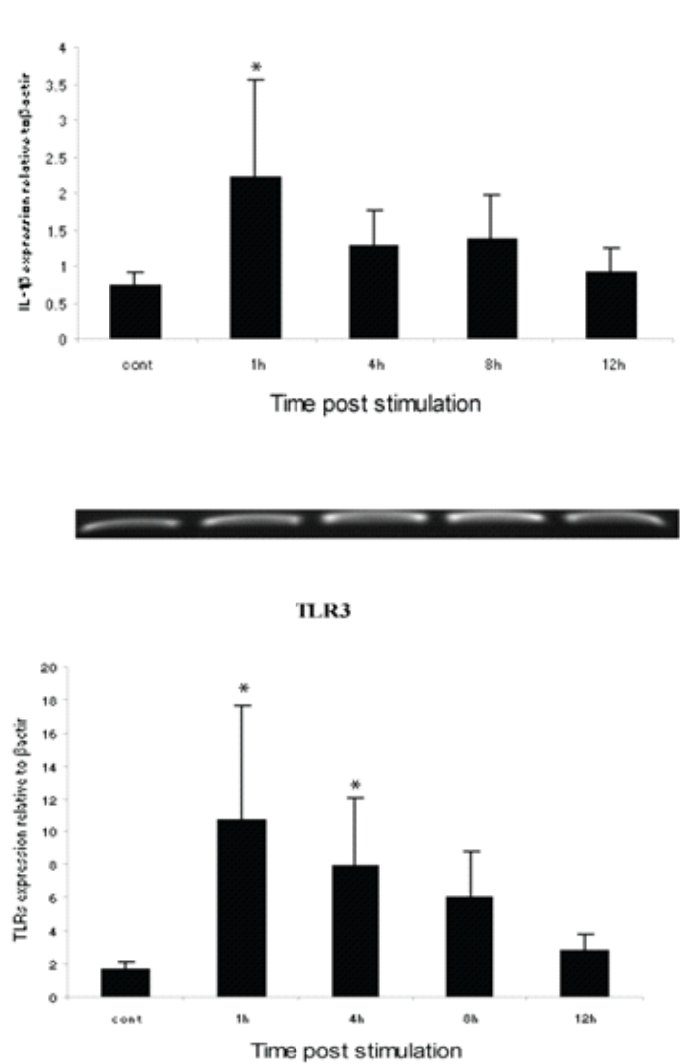

IL-10
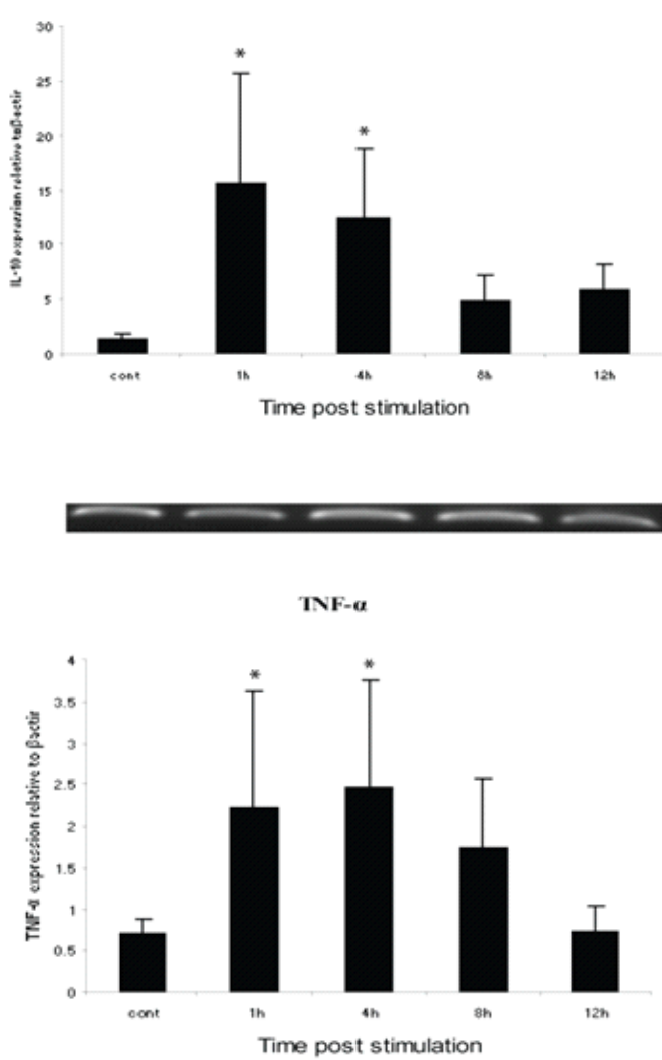

Figure 1. Expression analysis of IL-1, IL-10, TLR3 and TNF $\alpha$ in kidney of Cyprinus carpio after being stimulated with crude garlic extract

Garlic has been shown to have anti-inflammatory and pro-apoptotic properties among others. It was hypothesized that treating placental explants with garlic may inhibiit the production of inflammatory cytokines tumor necrosis factor (TNF- $\alpha)$. A reduction in TNF $\alpha$ production was evident at both low $(10 \mu \mathrm{g} / \mathrm{mL})$ and high $(500 \mu \mathrm{g} / \mathrm{mL}$ and $1000 \mu \mathrm{g} / \mathrm{mL})$ garlic concentrations in preeclamptic explants (Markis et al., 2004). TNF- $\alpha$ is an important pro-inflammatory cytokine. It is reported that allicin markedly inhibited the spontaneous TNF- $\alpha$ expression and TNF- $\alpha$-induced secretion of IL-1 $\beta$, from the two different cell lines in a dose-dependent manner and suppressed the expression of IL-1 $\beta$ mRNA level (Lang et al., 2002).

IL- $1 \beta$ is produced by macrophages, monocytes, and dendritic cells. IL- $1 \beta$ acting as an important mediator of the inflammatory response and is involved in a variety of cellular activities (Miliani et al., 2007). The expression of IL-1 $\beta$ was found to be higher than the controls $1 \mathrm{~h}$ post stimulation with garlic extract (Figure 1) giving onset up-regulation. This activation of IL-1 $\beta$ maybe related with the enhancement of macrophage functions. Fujiki et al. $(1999,2000)$ analyzed the expressed genes in HK of carp injected with sodium alginate and scleroglucan by suppression subtractive hybridization and reported the expression of immune-related genes like IL-1 $\beta$. Kono et al. (2002) demonstrated the activation of IL-1 $\beta$ in 
carp injected with PG. IL-1 $\beta$ expression in rainbow trout HK leucocytes is induced by LPS stimulation (Zou et al., 2000). Jørgensen et al. (2001) showed that CpG ODN 1668 activates trout macrophages to express IL-1 $\beta$. CpG ODN 1668, in concentrations varying from 2 to 20 $\mu \mathrm{M}$, also produced significant induction of IL-1 $\beta$ expression.

IL-10 is an immune-regulatory cytokine that influences the immunological system, both on the innate and cell-mediated response. The up-regulation of IL-10 was recorded at 1 and $4 \mathrm{~h}$ compared to the control group. The highest expression of the IL-10 gene was observed at $1 \mathrm{~h}$ (Fig.1). IL-10 expression has been identified in carp after LPS stimulation to the HK (Tanekhy et al., 2009). It was hypothesized that treating placental explants with garlic may stimulate the production of anti-inflammatory cytokines IL-10 by the placental explants. The lower concentration of garlic $10 \mu \mathrm{g} / \mathrm{mL}$ resulted in a significant increase in IL-10 production by normal placentas. However, higher concentrations of $500 \mu \mathrm{g} / \mathrm{mL}$ and $1000 \mu \mathrm{g} / \mathrm{mL}$ resulted in a marked decrease in IL-10 production (Markis et al., 2004). In the current study, the expression of the IL-10 gene was significantly increased at 1 and $4 \mathrm{~h}$ stimulation with allicin. IL-10 is generally known as an immunosuppressive cytokine. This is because, in rainbow trout and carp, IL-10, like other inflammatory cytokines such as TNF- $\alpha$, IL-1 $\beta$ is expressed soon after LPS stimulation, whereas in humans, IL-10 is not expressed so quickly (Inoue et al., 2005).

Toll-like receptors (TLRs) play an essential role in the innate immune system by initiating and directing immune responses to pathogens and control activation of adaptive immune responses. TLR3 triggers specific signaling pathways that culminate in the activation of NF-kB and IRF3 transcription factors, as well as apoptosis, enabling the host to mount an effective innate immune response through the induction of cytokines, chemokines, and other pro-inflammatory mediators.

In the present study, the expression of TLR3 was significantly increased 1 and $4 \mathrm{~h}$ post stimulation as compared to the control group. The highest expression of the IL-10 gene was observed at 1h (Figure 1). Poly I:C has been shown to bind TLR3. TLR3 deficient mice macrophages were shown to have greatly reduced responses to poly I:C. Human natural killer cells (NK cells) have been reported to express TLR3, to up-regulate TLR3 mRNA and cytotoxic activity following poly I:C stimulation.

Interferon (IFN) is a protein that is secreted from cells in response to invasion by pathogens, and is classified into type-I IFN (I-IFN) and type-II (II-IFN). IFN are produced in numerous cell types including lymphocytes ( $\mathrm{T}$ and $\mathrm{B}$ cells), macrophages, fibroblasts, blood vessel endothelial cells and osteogenetic cells, and are known to be important elements in antivirus reply (Samuel, 2001). In the present study, the expression of INF- $\alpha$ was significantly increased at 1 and $4 \mathrm{~h}$ compared to the control group. The highest expression of the INF- $\alpha$ gene was observed at $1 \mathrm{~h}$ (Figure 2). 


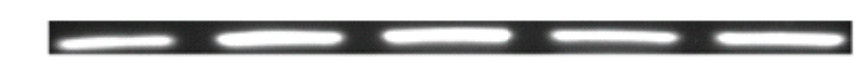

INF- $\alpha$
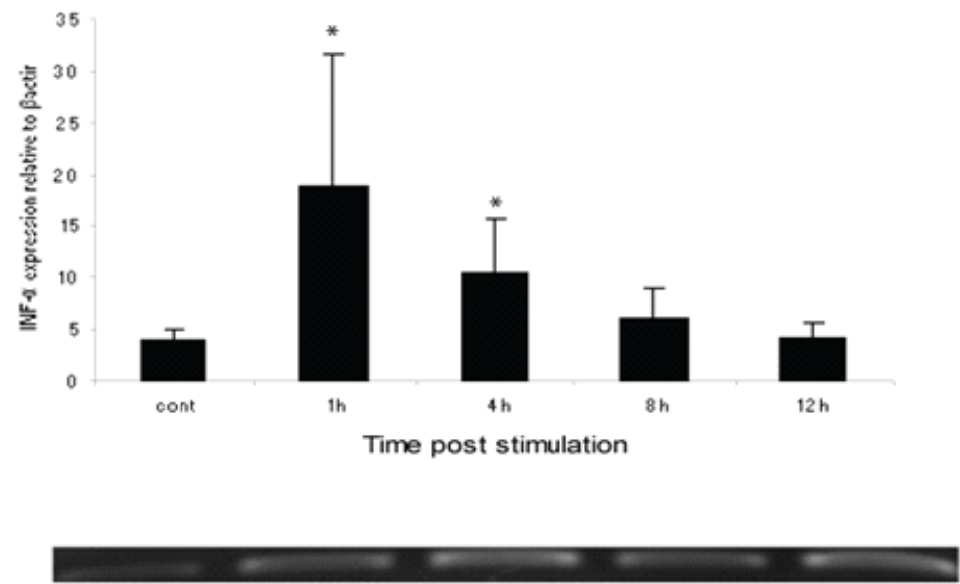

INF $\gamma 1$
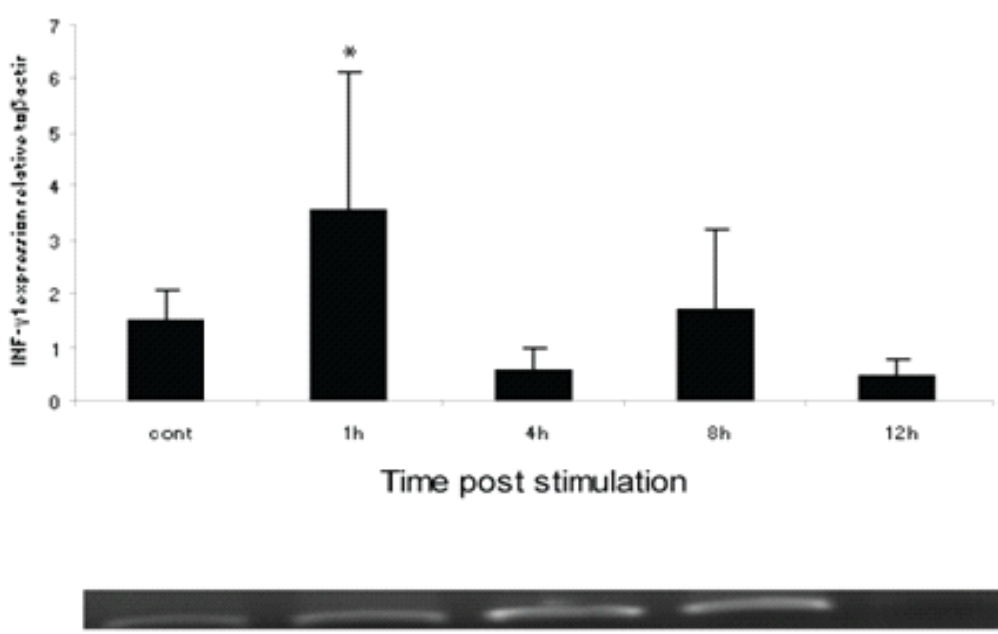

INFy 2
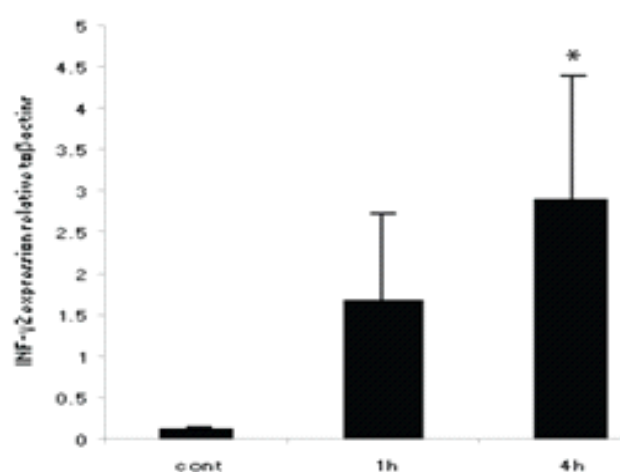

4h

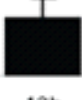

Time post stimulation

Figure 2. Expression analysis of interferons (INF $\alpha$, INF $\gamma 1$ and INF 2 ) in kidney of Cyprinus carpio after being stimulated with crude garlic extract 


\section{Macrothink}

The expression of INF $\gamma 1$ and was INF 2 was significantly higher than the control group at $1 \mathrm{~h}$ (Figure 2). The CpG ODN 1668 used has been shown by several different groups to stimulate immune mechanisms in higher vertebrates and recently it was reported to activate Atlantic salmon leucocytes to produce IFN-like cytokines (Jørgensen et al., 2001). There was no effect of different types of stimulants of IFN production, including LPS, poly I:C and the mitogen PHA, on the inducibility of the cell line in rainbow trout (Castro et al., 2010). PHA is a mitogen widely used to induce blastogenesis and mitosis in peripheral lymphocytes and to induce IFN-gamma expression. It was shown previously to strongly induce trout IFN-gamma expression in primary cultures of head kidney leucocytes at low doses $(10 \mathrm{mg} / \mathrm{ml})$. Using the same dose, Castro et al. (2010) have also detected a correlated expression in the primary cell line cultures after $4 \mathrm{~h}$ of PHA stimulation as an IFN-gamma induced gene. Recently, PHA was described as an activator for type I IFNs in RTG-2 cells using high concentrations of the lectin $(50 \mathrm{mg} / \mathrm{ml})$.

In conclusion, the present study documented that allicin activate both non-specific humoral immunity and non-specific cellular immune ability by increasing expression of cytokine genes in head kidney of carp. The potent immunostimulatory activities of allicin reported for fish in this study suggest allicin as an interesting immunostimulant to be tested in fish vaccines challenge test with pathogens.

\section{Acknowledgement}

The authors would like to thank Professor Mashiro Sakai for his outstanding support and also for performing the present work in his laboratory.

\section{References}

Agatha, A. N. (2012). The Effect of Garlic (Allium sativum) on Growth and Haematological Parameters of Clarias gariepinus (Burchell, 1822). Sustainable Agriculture Research, 1(2).

Braun-Nesje, R., Kaplan, G., Sejelid, R. 1982. Rainbow trout macrophages in vitro: Morphology and phagocytic activity. Dev. Comp Immunol, 6, 281-291. http://dx.doi.org/10.1016/S0145-305X(82)80011-6

Bicknell, R. A. Salmo. (2005). The use of immunostimulants in fish larval aquaculture. Fish Shellfish Immunol, 19, 457-472. http://dx.doi.org/10.1016/j.fsi.2005.03.008

Castillo, J., Tales, M., Mackenzie, S., Tort, L. 2009. Stress-related hormones modulate cytokine expression in the head kidney of gilthead Seabream (Sparus aurata). Fish shellfish Immunol, 2, 493-499. http://dx.doi.org/10.1016/j.fsi.2009.06.021

Castro, R., Martin, S. A. M., Zou, J., \& Secombes, C. J. (2010). Establishment of an IFN-g specific reporter cell line in fish. Fish shellfish Immunol, 28, 312-319. http://dx.doi.org/10.1016/j.fsi.2009.11.010

Cavalitto, C., \& Bailey, J. H. (1944). Allicin, the antibacterial principle of Allium sativum. Isolation, physical properties and antibacterial action. $J$ AM Chem Soc, 66 . http://dx.doi.org/10.1021/ja01239a048

Celiini, L., Di Campli, B., Masulli, M., Di Bartolomeo, S., \& Aliocati, N. (1996). Inhibition of Helicobacter pylori by garlic extract (Allium satvium). FEM Immenol Med Micrbiol, 13, 273-277. http://dx.doi.org/10.1111/j.1574-695X.1996.tb00251.x 
Corzo-Martinez, M., Corzo, N., \& Villamiel, M. (2007). Biological properties of onions and garlic. Trends Food Sci Techn, 18, 609-625. http://dx.doi.org/10.1016/j.tifs.2007.07.011

Elmore, G. S., \& Feldberg, R. S. (1994). Alliin lyase localization in bundle sheaths of garlic clove (Allium sativum). Am J Bat, 81, 89-94. http://dx.doi.org/10.2307/2445567

Ferrero-Miliani, L., Nielsen, O. H., Andersen, P. S., \& Girardin, S. E. (2007). Chronic inflammation: importance of NOD2 and NALP3 in interleukin-1 $\beta$ gemeration. Clin Exp Immunol, 147(2), 227-235.

Fujiki, K., Shin, D. H., Nakao, M., \& Yano, T. (2000). Molecular cloning and expression analysis of carp (Cyprinus carpio) interleukin-1 beta, high affinity immunoglobulin E Fc receptor gamma subunit and serum amyloid A. Fish shellfish Immunol, 10(3), 229-42. http://dx.doi.org/10.1006/fsim.1999.0253

Gonzalez-Fandoz, F., Garcia-Lopez, M., Sierra, M., \& Otero, A. (1994). Staphylococcal growth and enterotonxins (A-D) and thermonuclease synthesis in the presence of dehydrated garlic. J Appl Bacteriol, 77, 549-552. http://dx.doi.org/10.1111/j.1365-2672.1994.tb04400.x

Hirono, I., Nam, B. H., Kurobe, T., \& Aoki, T. (2000). Molecular cloning, characterization, and expression of TNF cDNA and gene from Japanese flounder Paralychthys olivaceus. $J$ Immunol, 165(8), 4423-7. http://dx.doi.org/10.4049/jimmunol.165.8.4423

Huges, E. G., \& Lawson, L. D. (1991). Antimicrobial effects of Allium sativum L. (garlic) Allium ameelopratrum (elephant garlic) and Allium cepa (onion) garlic compounds and commercial grade garlic supplements. Phytothet Res, 5, 154-158. http://dx.doi.org/10.1002/ptr.2650050403

Inoue, Y., Kamota, S., Ito, K., Yoshiura, Y., Ototake, M., Moritomo, T., \& Nakanishi, T. (2005). Molecular cloning and expression analysis of rainbow trout (Oncorhynchus mykiss) interleukin-10 cDNAs. Fish Shellfish Immunol, 18, 335-344. http://dx.doi.org/10.1016/j.fsi.2004.08.004

Jørgensen, J. B., J. Zou, A. Johansen, C., \& Secombes, J. (2001). Immunostimulatory CpG oligodeoxynucleotides stimulate expression of IL-1beta and interferon-like cytokines in rainbow trout macrophages via a chloroquine-sensitive mechanism. Fish Shellfish Immunol, 11, 673-682. http://dx.doi.org/10.1006/fsim.2001.0344

Koch, H. P., \& Lawson, L. D. (1996). Garlic, the science and therapeutic application of Allium sativum L. and related species. In D. C. Retford (Ed), Williams and Wilkins, Baltimore (pp. 1-233).

Kitao, Y., Kono, T., Korenaga, H., Iizasa, T., Nakamura, K., Savan, R., \& Sakai, M. (2009). Characterization and expression analysis of type I interferon in common carp, Cyprinus carpio L. Mol Immunol, 46, 2548-2556. http://dx.doi.org/10.1016/j.molimm.2009.05.012

Kono, T., Ponpornpisit, A., \& Sakai, M. (2004). The analysis of expressed genes in head kidney of common carp, Cyprinus carpio L. stimulated with peptidoglycan. Aquaculture, 235, 37-52. http://dx.doi.org/10.1016/S0044-8486(03)00447-2

Lang, R., D. Patel, J. J., Morris, R. L., \& Rutschman, P. J. (2002). Shaping gene expression in activated and resting primary macrophages by IL-10. J Immunol, 169, 2253-2263. http://dx.doi.org/10.4049/jimmunol.169.5.2253 
Makris, C. E, Thornton, B., \& Xu, A. (2004). Garlic increases IL-10 and inhibits TNF $\alpha$ and IL-6 production in endotoxin-stimulated human placental explants. Placenta, 26(10), 828-834. http://dx.doi.org/10.1016/j.placenta.2004.10.019

Miron, T., Rabinkov, A., Mirelman, D., Wilchek, M., \& Weiner, L. (2000). The mode of action of allicin: Its ready permeability through phospholipid membranes may contribute to its biological activity. Biochim Biophys Acta, 1463, 20-30. http://dx.doi.org/10.1016/S0005-2736(99)00174-1

Miron, T., Bercovici, T., Rabinkov, A., Wilchek, M., \& Mirelman, D. (2004). allicin: preparation and applications. Anal Biochem, 331, 364-369. http://dx.doi.org/10.1016/j.ab.2004.03.054

Nya, E. J., \& Austin, B. (2009). Use of garlic, Allium sativum, to control Aeromonas hydrophila infection in rainbow trout, Oncorhynchus mykiss (Walbaum). J Fish Dis, 32, 963-970. http://dx.doi.org/10.1111/j.1365-2761.2009.01101.x

Rabinkov, A., Miron, T., Konsrantinovski, L., Wilchek, M., Mirelman, D., \& Weiner, L. (1998). The mode of action of allicin: Trapping of radicals and interaction with thiol containing proteins. Biochim Biophys Acts, 1379, 233-244. http://dx.doi.org/10.1016/S0304-4165(97)00104-9

Rose, P., Whiteman, M., Moore, P. K., \& Zhu, Y. Z. (2005). Bioactive S-alk(en)yl cysteine sulfoxide metabolites in the genus Allium. The chemistry of potential therapeutic agents. Natural Product Reports, 22, 351-368. http://dx.doi.org/10.1039/b417639c

Savan, R., Igawa, D., \& Sakai, M. (2003). Cloning, characterization and expression analysis of interleukin10 from the common carp, Cyprinus carpio L. Eur J Biochem, 270(23), 4647-4654. http://dx.doi.org/10.1046/j.1432-1033.2003.03854.x

Savan, R., \& Sakai, M. (2006). Genomics of fish cytokines. Comp Bioch Physiol, 1, 89-101. http://dx.doi.org/10.1016/j.cbd.2005.08.005

Samuel, C. E. (2001). Antiviral actions of interferons. Clin Microbiol Rev, 14(4), 778-809. http://dx.doi.org/10.1128/CMR.14.4.778-809.2001

Saeij, J. P., Stet, R. J., de Vries, B. J., van Muiswinkel, W. B., \& Wiegertjes, G. F. (2003). Molecular and functional characterization of carp TNF: A link between TNF polymorphism and trypanotolerance? Dev Comp Immunol, 27(1), 29-41. http://dx.doi.org/10.1016/S0145-305X(02)00064-2

Shahsavani, D., Baghshani, H., \& Alishahi, E. (2011). Efficacy of allicin in decreasing lead $(\mathrm{Pb})$ accumulation in selected tissues of lead-exposed common carp (Cyprinus carpio). Biol Trace Elem Res, 142, 572-580. http://dx.doi.org/10.1007/s12011-010-8801-3

Santhosha, S. G, Prakash, J., \& Prabhavathin, S. N. (2013). Bioactive components of garlic and their physiological role in health maintenance: A review. Food Bioscience, 3, 59-74. http://dx.doi.org/10.1016/j.fbio.2013.07.001

Tanekhy, M., Kono, T., \& Sakai, M. (2009). Expression profile of cytokine genes in the common carp species Cyprinus Carpio L. following infection with Aeromonas hydrophila. Bull Eur Ass Fish Pathol, 29, 197-203.

Tanekhy, M., Kono, T., \& Sakai, M. (2010). Cloning, characterization, and expression 
analysis of Toll-like receptor-7 cDNA from common carp, Cyprinus carpio L. Comp Biochem Physiol Part D, 5, 245-255. http://dx.doi.org/10.1016/j.cbd.2010.07.001

Yamada, Y., \& Azuma, K. (1997). Evaluation of the in vitro anti-fungal activity of allicin. Antimicrob Agents Chemothe, 1, 743-749.

Vilcek, J. (2003). Fifty years of interferon research: aiming at a moving target. Immunity, 25, 343-8. http://dx.doi.org/10.1016/j.immuni.2006.08.008

Wang, T., \& Secombes, C. J. (2013). The cytokine networks of adaptive immunity in fish. Fish Shellfish Immunol, 35(6), 1703-1718. http://dx.doi.org/10.1016/j.fsi.2013.08.030

Zou, J., Peddie, S., Scapigliati, G., Zhang, Y., Bols, N. C., Ellis, A. E., \& Secombes, C. J. (2003). Functional characterization of rTNF in rainbow trout. Onchorhyncus mykiss. Dev Comp Immunol, 27, 813-822. http://dx.doi.org/10.1016/S0145-305X(03)00077-6

\section{Copyright Disclaimer}

Copyright reserved by the author(s).

This article is an open-access article distributed under the terms and conditions of the Creative Commons Attribution license (http://creativecommons.org/licenses/by/3.0/). 